\title{
Association of the killer immunoglobulin- like receptor genes KIR2DS1 and KIR2DS4 with pediatric autoimmune hepatitis type I in Egypt
}

\author{
Ola Galal Behairy ${ }^{1}$ (D), Ola Samir El-Shimi ${ }^{2 *}$, Naglaa Hamed Shalan ${ }^{3}$ (D) and Shaymaa Mohamed Baghdady ${ }^{4}$ (D)
}

\begin{abstract}
Background: Killer cell immunoglobulin-like receptors (KIR) are considered to be the key receptors that control the development and function of human natural killer cells which play complex mechanisms in autoimmune diseases. We aimed in this study to assess possible associations between killer cell immunoglobulin-like receptors (KIR2DS1 and 2DS4) genes and susceptibility to autoimmune hepatitis type I in Egyptian children.

Results: In the case-control study conducted on eighty children diagnosed as autoimmune hepatitis (AlH) type I and eighty apparently healthy age and sex-matched control, we found that KIR2DS1, -2DS4, KIR2DS4-full length allele, and homozygous KIR2DS4-full/full variant were significantly associated with AlH-I, while the KIR1D allele and homozygous KIR2DS4-del/del variant were significantly observed in controls ( $P<0.05$ each). Absence of KIR2DS4 gene was significant among ANA positive AlH-I patients, patients on steroid therapy alone, and patients showing complete disease remission $(P<0.05$ each). Higher activity and fibrosis indices were found significantly in patients lacking one or both studied genes.

Conclusions: Children carrying KIR2DS1, -2DS4 genes, KIR2DS4-full length allele, and homozygous KIR2DS4-full/full variant could be more susceptible to develop autoimmune hepatitis type I.
\end{abstract}

Keywords: Autoimmune hepatitis, KIR, KIR2DS1, KIR2DS4, Egypt

\section{Background}

Autoimmune hepatitis (AIH) is a chronic progressive inflammatory disease of the liver, characterized by elevated serum aminotransferases, hypergammaglobulinemia, non-organ-specific autoantibodies, and lymphoplasmacytic interface hepatitis and responded to immunosuppressive therapy. It affects all ethnicity, any age, and both sexes, with female predominance [1]. According to the autoantibodies profile, AIH is classified into two main types (type I and type II), and whether AIH is treated or not, it might end up with liver cirrhosis [2]. The etiology

\footnotetext{
* Correspondence: ola.samer@fmed.bu.edu.eg

${ }^{2}$ Clinical and Chemical Pathology Department, Faculty of Medicine, Benha University, Benha 13511, Egypt

Full list of author information is available at the end of the article
}

of AIH remains largely unresolved. Hence, the interaction between background genetic architecture, environmental factors, and defective immune system can lead to AIH via the induction of a $\mathrm{T}$ cell-mediated immune response against liver antigens [3].

Natural killer (NK) cells have central roles in the innate immune response to viruses, bacteria, and tumor cells [4]. They can mediate direct killing of viral infected and transformed target cells as well as secreting immune regulatory cytokines and chemokines that bridge both innate and adaptive immune systems and activating the adaptive immune response [5]. NK cell-mediated responses have been implicated in the pathogenesis of $\mathrm{AIH}$ and other autoimmune diseases [6-8]. In peripheral blood, NK cells (CD16+ and CD56+) constitute only $5-10 \%$ of the 
circulating lymphocytes. However, they represent about $30 \%$ of the total lymphocytes in hepatic tissue and may reach up to $50 \%$ in case of liver pathologies such as viral, immune-mediated liver diseases and allograft rejection [9].

NK cells express a broad spectrum of inhibitory and activating killer cell immunoglobulin-like receptors (KIRs) that regulate their activity via detection of the expression levels of MHC class I on normal and diseased cells in humans [10].

Human KIR gene family is encoded by highly homologous sequences located on chromosome 19q13.4 within the leukocyte receptor complex (LRC) [11]. A total of 17 KIR genes have been discovered and named based on the molecule structure they encode (KIR2DL1-5A and B, KIR2DS1-5, KIR3DL1-3, KIR3DS1, KIR2DP1, and KIR3DP1). The first digit after the KIR acronym represents the number of Ig-like domains " $\mathrm{D}$ " in the molecule. The "L," "S," or "P" letters indicate a "long," "short," cytoplasmic tails, or a pseudogene respectively. The number of the gene encoding the protein with this structure is represented by a final digit. When two or more genes have very similar structures and sequences, a final letter is given after the same number to distinguish them (KIR2DL5A and KIR2DL5B) [12].

Early population studies of KIR genotypes demonstrated variations in KIR gene content from individual to individual (49-55). Based on these studies, two major KIR haplotype groups, the A and B haplotypes, have emerged (49). The A haplotype has traditionally been defined as containing KIR3DL3, -2DL3, -2DL1, -2DL4, -3DL1, -2DS4, and -3DL2. In contrast, B haplotypes are more variable and characterized by the presence of more than one activating KIR gene. Based on population studies of KIR genotypes, two major KIR haplotype groups have been described, the A and B haplotypes. Group A haplotypes contain fixed number of genes (the inhibitory KIR3DL3, -2DL1, -2DL3, -2DL4, $-3 D L 1$, and $-3 D L 2$ genes and the activating KIR2DS4 gene) while the Group B haplotypes contain different combinations of both activating and inhibitory KIR genes including one or more of the following genes: KIR2DS1, -2DS2, -2DS3, -2DS5, $-3 D S 1,-2 D L 2,-2 D L 5 A$, and $-2 D L 5 B$ genes $[13,14]$.

Few studies have been reported the association of KIR gene complexes with AIH susceptibility [15-17]. Therefore, we aimed to study the possible associations of KIR2DS1 and 2DS4 genes with AIH-I susceptibility in a group of Egyptian children.

\section{Methods}

\section{Study population}

This case-control study included 160 children divided into 2 groups; an AIH group included 80 children with $\mathrm{AIH}$ diagnosed according to the International Autoimmune Hepatitis Group (IAIHG) revised original scoring system and the simplified diagnostic scoring system of the IAIHG [18], referred to pediatric hepatology clinics in Benha University Hospitals and National Liver Institute-Menoufia University, between May 2015 and January 2019. Any child with other chronic liver diseases and/or comorbidity as cardiovascular, renal, or central nervous systems affection was excluded. The second group is the control group, which included 80 apparently healthy children selected from general population of matched age and sex with the patient group.

\section{Methodology}

Each patient underwent full history taking, comprehensive clinical examination, abdominal ultrasonography, and routine laboratory investigations. In order to diagnose $\mathrm{AIH}$, patients were tested for anti-nuclear antibody (ANA), anti-smooth muscle antibody (ASMA), liverkidney microsomal antibody type 1 (LKM-1), and antimitochondrial antibody (AMA) by indirect immunofluorescence technique using Nova Lite ${ }^{\bullet}$ ANA KSL (Mouse Kidney/Stomach/Liver) (Inova Diagnostics, Barcelona, Spain). According to seropositivity for autoantibodies, patients with ANA and/or ASMA with titer $\geq 1$ : 20 were classified as AIH-I and patients with LKM-1 titer $\geq 1: 40$ were classified as AIH-II [19]. To exclude other causes of liver disease before patients assigned for liver biopsy, hepatitis viruses (B, C, E) as well as cytomegalovirus (CMV) and Epstein-Barr virus (EBV) were screened for their serological markers (HBs-Ag, anti$\mathrm{HBc}$, anti-HCV, anti-HEV, anti-CMV-IgM, anti-EBNAIgM, and anti-VCA-IgM) and confirmed with RT-PCR. Wilson's disease was excluded by estimating serum ceruloplasmin, $24 \mathrm{~h}$ urinary copper before and after penicillamine and the presence of Keyser-Fleischer rings. An ultrasound-guided liver biopsy was performed for all patients using Menghini aspiration needle to obtain an adequate core containing at least 11 portal tracts (Hepafix Luer Lock Braun Melsungen AG, Melsungen, Germany). Formalin-fixed, paraffin-embedded biopsy specimens were cut and stained with hematoxylin and eosin to evaluate histological activity of hepatitis using Ishak hepatitis activity index (HAI), Mason-Trichrome stain to assess degree of fibrosis, Perls' Prussian blue stain to detect iron deposition, and periodic acid-Schiff (PAS) stain to exclude $\alpha 1$ anti-trypsin deficiency. HAI ranges from 0 to 18 and the total activity scores are defined as follows: 1-3 minimal, 4-8 mild, 9-12 moderate, and $13-18$ severe activity, while the degree of fibrosis is defined as follows: 0 no fibrosis, 1 fibrous expansion of some portal areas, with or without short fibrous septa, 2 fibrous expansion of most portal areas, with or without short fibrous septa, 3 fibrous expansion of most portal areas with occasional portal to portal bridging, 4 fibrous expansion of most portal areas with marked bridging 
(portal to portal as well as portal to central), 5 marked bridging with occasional nodules (incomplete cirrhosis), and 6 cirrhosis, probable or definite [20].

\section{KIR genotyping}

Genomic DNA from all participants was extracted from whole blood collected on EDTA tubes using GeneJET Whole Blood Genomic DNA Purification Mini Kit (Thermo-Fisher Scientific, Germany) according to the manufacturer's instructions. The isolated DNA concentration and purity were evaluated by NanoDrop ${ }^{\mathrm{TM}} 2000$ (Thermo-Fisher Scientific, USA). Genotyping of KIR2DS1 and the full-length KIR2DS4 (KIR2DS4-FL) with its variant KIR1D (it is identical to 2DS4 except for a $22 \mathrm{bp}$ deletion in the sequences encoding the second Ig domain; D2) were performed separately by PCR with sequence-specific primers (PCR-SSP) using $\mathrm{MyTaq}^{\mathrm{TM}}$ Red Mix (2X) (BIOLINE, UK) and primers [21] (Biosearch technologies, UK) on Veriti Dx Thermal Cycler (Thermo-Fisher Scientific, USA) programmed with a 2min denaturation step at $94{ }^{\circ} \mathrm{C}$, followed by 30 cycles of $92^{\circ} \mathrm{C}$ for $10 \mathrm{~s}, 65^{\circ} \mathrm{C}$ for $30 \mathrm{~s}$, and $68^{\circ} \mathrm{C}$ for $1 \mathrm{~min} 30 \mathrm{~s}$, followed by $72^{\circ} \mathrm{C}$ for $10 \mathrm{~min}$. Annealing temperatures were modified for primers amplifying KIR2DS4 $\left(61^{\circ} \mathrm{C}\right)$ and $\operatorname{KIR} 1 D\left(63^{\circ} \mathrm{C}\right)$. The PCR products along with $100 \mathrm{bp}$ marker were resolved by electrophoresis in $2.5 \%$ agarose gel stained with $0.3 \mu \mathrm{g} / \mathrm{ml}$ ethidium bromide. The bands were visualized using UV trans-illuminator at $254 \mathrm{~nm}$ (Fig. 1).

\section{KIR haplotype group assignment}

Depending on the two studied KIR genes, the presence of KIR2DS4 gene is indicating KIR haplotype A, while the KIR haplotype B could contain KIR2DS1 gene or not. Thus, the homozygous individuals for KIR haplotype A (KIR AA) could be differentiated from heterozygous or homozygous individuals for KIR haplotype B (KIR AB or BB, referred together as KIR Bx) [22].

\section{Statistical analysis}

Data were summarized in terms of mean \pm standard deviation (SD) or median (range) for quantitative data and frequency (percentage) for qualitative data. Student's $t$ test and the Mann-Whitney $(Z)$ test were used to test differences between two groups regarding parametric and non-parametric data respectively, while the chisquare $\left(\chi^{2}\right)$ and Fisher exact (FE) tests were used to compare frequencies as appropriate. To quantify the strength of the association of studied genotypes, odds ratio (OR) and $95 \%$ confidence interval $(\mathrm{CI})$ were calculated. Statistical significance was accepted at $P$ value $<0.05$. All statistical analyses were carried out using STATA/SE version 11.2 for Windows (STATA Corporation, College Station, Texas).

\section{Results}

\section{Study population characteristics}

The mean age of the eighty studied patients was $7.8 \pm$ 3.62 years. They were 46 (57.5\%) females and 34 (42.5\%) males with female to male ratio 1.3:1, while the 80 control children had a mean age 7.2 \pm 3.42 years with a female to male ratio 1:1. The AIH patients presented clinically with jaundice (78\%), fatigue (35\%), abdominal pain (48.5\%), abdominal distention (50\%), fever (15\%), and gastrointestinal bleeding (10\%). Abdominal ultrasonography of patients revealed hepatomegaly (70\%), splenomegaly (25\%), and ascites (25\%). Only 6 patients (7.5\%) had previous or concomitant immune-mediated diseases in the form of arthritis or eczema. Family history of autoimmune disease-rheumatoid arthritis or systemic lupus erythematosus-in first degree relatives was positive in 10 patients (12.5\%). All studied patients were AIH type I (anti-LKM-1 or AMA negative). Sixteen patients $(23.5 \%)$ were ANA positive and 68 patients (85\%) were ASMA positive with titer ranged from 1:20 to $1: 80$. The baseline biochemical and histopathological characteristics of patients are listed in (Table 1). By applying scoring system for AIH diagnosis, we found that the frequency of definite diagnosis of $\mathrm{AIH}$ by revised

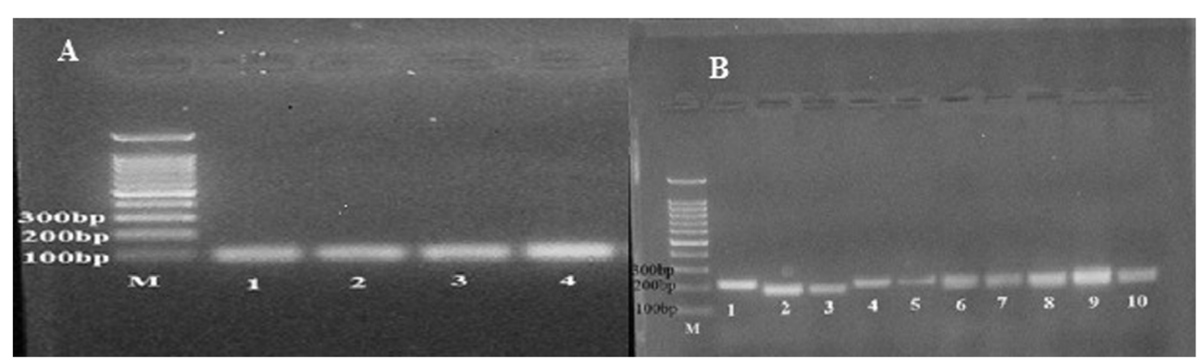

Fig. 1 KIR genotyping. A KIR2DS1 gene: samples 1-4 show the 102 bp fragment. B KIR2DS4 gene: samples 1, 4, and 5 are full/full (homozygous full length) at $219 \mathrm{bp}$, samples 2 and 3 are del/del (homozygous deletion variant) at $197 \mathrm{bp}$, and samples 6-10 are full/del (heterozygous). M: 100 bp marker. Primers sequences: KIR2DS1 [F: 5'-TCTCCATCAGTCGCATGAA/G-3', R: 5'-AGGGCCCAGAGGAAAGTT-3'], KIR2DS4-FL [F: 5'-ATCCTGCAATGT TGGTCG-3', R: 5'-CTGGATAGATGGTACATGTC-3'], KIR1D [F: 5'-ATCCTGCAATGTTGGTCG-3', R: 5'-CTGGATAGATGGAGCTGCAG-3'] [21] 
Table 1 Baseline characteristics of AlH-I patients $(n=80)$

\begin{tabular}{|c|c|c|}
\hline \multicolumn{2}{|l|}{ Rinchemical characteristics } & AlH-1 \\
\hline \multicolumn{3}{|l|}{ Biochemical characteristics } \\
\hline \multicolumn{2}{|l|}{ Aspartate aminotransferase (AST; U/L) } & $230(57-960)$ \\
\hline \multicolumn{2}{|l|}{ Alanine aminotransferase (ALT; U/L) } & $230(17-825)$ \\
\hline \multicolumn{2}{|l|}{ Alkaline phosphatase (ALP; U/L) } & $200(55-613)$ \\
\hline \multicolumn{2}{|l|}{ Gamma glutamyl transferase (GGT; U/L) } & $68(22-100)$ \\
\hline \multicolumn{2}{|l|}{ Prothrombin time (PT; sec) } & $16.3(12-28)$ \\
\hline \multicolumn{2}{|c|}{ Activated partial thromboplastin time (aPTT; sec) } & $44(26-55)$ \\
\hline \multicolumn{2}{|l|}{ International normalized ratio (INR) } & $1.6(1-3.4)$ \\
\hline \multicolumn{2}{|l|}{ Serum total bilirubin $(\mu \mathrm{mol} / \mathrm{L})$} & $51.3(5.13-353.97)$ \\
\hline \multicolumn{2}{|l|}{ Serum direct bilirubin $(\mu \mathrm{mol} / \mathrm{L})$} & $34.2(1.71-263.34)$ \\
\hline \multicolumn{2}{|l|}{ Serum albumin $(g / L)$} & $32(20-44)$ \\
\hline \multicolumn{2}{|l|}{ Serum total proteins (g/L) } & $80(48-100)$ \\
\hline \multicolumn{2}{|c|}{ Serum total immunoglobulin $\mathrm{G}(\operatorname{lgG} ; \mu \mathrm{mol} / \mathrm{L})^{\mathrm{a}}$} & $220.15(60.37-375.32)$ \\
\hline \multicolumn{3}{|l|}{ Histopathological characteristics } \\
\hline \multirow[t]{3}{*}{ Infiltrating inflammatory cells } & Eosinophil & $8(10)$ \\
\hline & Lymphocytes & $16(45)$ \\
\hline & Plasma cells & $66(82)$ \\
\hline \multirow[t]{3}{*}{ Hepatocytes and portal tracts changes } & Ballooning and degeneration of hepatocytes & $4(5)$ \\
\hline & Rosettes formation & $16(20)$ \\
\hline & interface hepatitis (piecemeal necrosis and bridging) & $64(80)$ \\
\hline \multicolumn{2}{|l|}{ Hepatitis activity index (HAl) } & $7(1-15)$ \\
\hline \multicolumn{2}{|l|}{ Degree of fibrosis } & $3(0-5)$ \\
\hline
\end{tabular}

Data are given either median (range) or number (\%)

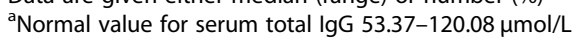

original scoring system of the IAIHG compared to simplified scoring system was $65 \%$ vs. $70 \%$, respectively, and probable diagnosis of $\mathrm{AIH}$ was $35 \%$ vs. $30 \%$, respectively. According to Child-Pugh classification, 23 (28.8\%) of studied patients were class A, 49 (61.2\%) class B, and 8 (10\%) were class $\mathrm{C}$. All our patients received steroid as an initial therapy (prednisolone $2 \mathrm{mg} / \mathrm{kg} /$ day; maximum $60 \mathrm{mg} /$ day that was gradually tapered by $5 \mathrm{mg}$ every $1-2$ weeks based on the clinical symptoms, AST and ALT levels with $10 \mathrm{mg}$ prednisolone for 2 years after improvement as a maintenance dose), and azathioprine (1-2 $\mathrm{mg} / \mathrm{kg} /$ day; maximum $100 \mathrm{mg} /$ day) was added to 54 patients who showed an increased AST or ALT levels during tapering steroid or who had significant side effects that necessitate reducing the dose of steroid (like severe cosmetic changes, duodenal ulcer, hypertension or corticosteroid-related osteopenia detected by bone densitometry). Complete remission (which is the normalization of liver enzymes and absence of clinical symptoms; normal ALT on a minimum of two occasions at least a month apart) was observed in 46 (57.5\%) patients, and $34(42.5 \%)$ patients had relapses (in which at least twofold increase in AST or ALT in isolation or in combination with histological evidence of disease activity).

\section{KIR frequencies in AlH-1 patients and controls}

Both KIR2DS1 and 2DS4 genes were found to be significantly associated with the risk of development of AIH-I (85\% in patients vs. $30 \%$ in controls; $P<0.001$, OR 13.22 and $92.5 \%$ vs. $62.5 \% ; P<0.001$, OR 7.4 respectively). As regards the KIR2DS4 alleles, KIR2DS4-full length allele was significantly detected in $75.7 \%$ of patients, whereas the KIR2DS4 22 bp deletion allele (KIR1D) was significantly observed in $80 \%$ of controls $(P=0.002$, OR 12.44). The most significantly frequent KIR2DS4 variant in AIH-I patients was homozygous full length variant (KIR2DS4-full/full) (45.94\%), while the homozygous deleted variant (KIR2DS4$\mathrm{del} / \mathrm{del})$ was predominant among controls $(68 \%)(P=$ 0.003) (Table 2). Studying KIR haplotypes revealed that the KIR Bx haplotype was more frequent in AIH-I patients (85\%), while the KIR AA haplotype was more frequent in controls $(70 \%)(P<0.001$, OR 13.22) (Table 2).

By studying the association between KIR2DS1 and KIR2DS4 genes with some disease characteristics in AIH-I patients, we observed that lacking the KIR2DS4 gene was significantly associated with positive ANA $(P<$ $0.001)$, patients treated with steroid alone $(P=0.008)$, and patients had a complete remission $(P=0.036)$. We 
Table 2 KIR frequencies in type I AlH and healthy individuals

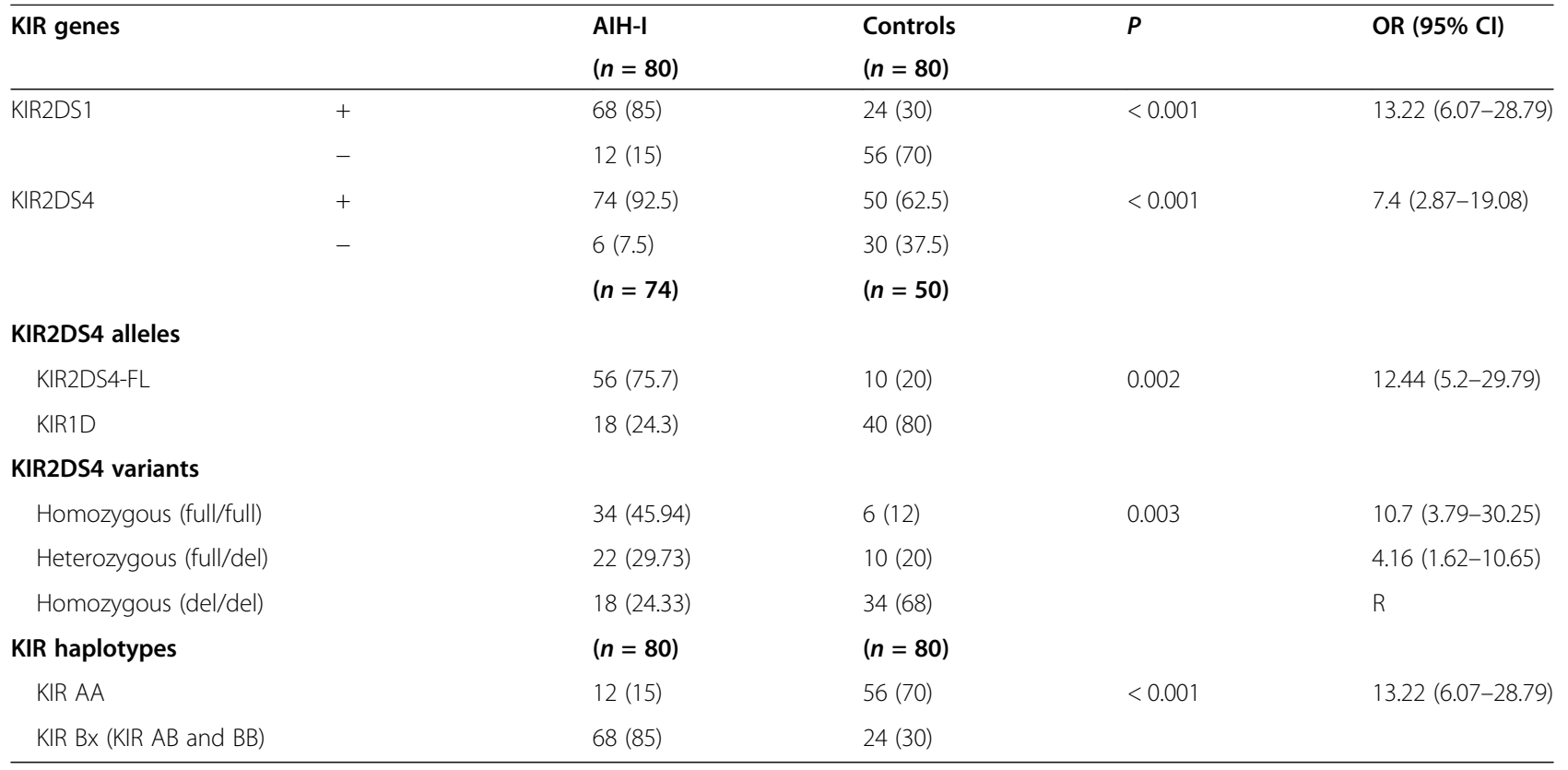

Data are given as number (\%)

+, present gene; -, absent gene; KIR1D, 22 bp deletion variant of KIR2DS4-full length; R, reference genotype

found that lacking both KIR2DS1 and KIR2DS4 genes were significantly associated with higher hepatitis activity index (HAI) $(P=0.006$ and 0.012 respectively). Meanwhile, the absence of KIR2DS4 gene was significantly associated with higher degree of fibrosis $(P=$ 0.043) (Table 3).

\section{Discussion}

AIH is a serious autoimmune liver disease affecting both children and adults with a female predominance and more aggressive course among children [2]. Despite extensive studies trying to approach AIH pathogenesis, the exact mechanisms are still unknown [23]. Many studies

Table 3 Comparison of studied KIR activating genes and some disease characteristics in AlH-I patients

\begin{tabular}{|c|c|c|c|c|c|c|}
\hline & \multicolumn{3}{|l|}{ KIR2DS1 } & \multicolumn{3}{|l|}{ KIR2DS4 } \\
\hline & $\begin{array}{l}++ \\
(N=68)\end{array}$ & $\overline{(N=12)}$ & $P$ & $\begin{array}{l}+ \\
(N=74)\end{array}$ & $\overline{(N=6)}$ & $P$ \\
\hline \multicolumn{7}{|c|}{ Anti-nuclear antibodies (ANA) } \\
\hline Negative & $52(76.5)$ & $12(100)$ & 0.32 & $64(86.5)$ & 0 & $<0.001$ \\
\hline Positive & $16(23.5)$ & 0 & & $10(13.5)$ & $6(100)$ & \\
\hline \multicolumn{7}{|c|}{ Anti-smooth muscle antibodies (ASMA) } \\
\hline Negative & $10(14.7)$ & $2(16.7)$ & 1.00 & $12(16.2)$ & 0 & 1.00 \\
\hline Positive & $58(85.3)$ & $10(83.3)$ & & $62(83.8)$ & $6(100)$ & \\
\hline \multicolumn{7}{|l|}{ Treatment regimen } \\
\hline Steroid & $22(32.3)$ & 4.(33.3) & 1.00 & $20(27)$ & $6(100)$ & 0.008 \\
\hline Steroid and azathioprine & $46(67.7)$ & $8(66.7)$ & & $54(73)$ & 0 & \\
\hline \multicolumn{7}{|l|}{ Treatment response } \\
\hline Complete remission & $40(58.8)$ & $6(50)$ & 1.00 & $40(54)$ & $6(100)$ & 0.036 \\
\hline Relapse & $28(41.2)$ & $6(50)$ & & $34(46)$ & 0 & \\
\hline \multicolumn{7}{|l|}{ Hepatitis Activity Index (HAI) } \\
\hline & $7.06 \pm 2.89$ & $9.83 \pm 4.44$ & 0.006 & $7.22 \pm 3.21$ & $10.67 \pm 2.31$ & 0.012 \\
\hline \multicolumn{7}{|l|}{ Degree of fibrosis } \\
\hline & $2.94 \pm 1.01$ & $2.67 \pm 0.52$ & 0.369 & $2.84 \pm 0.9$ & $3.67 \pm 1.53$ & 0.043 \\
\hline
\end{tabular}

Data are given either number (\%) or mean \pm SD

+ , present gene; -, absent gene 
have focused on the adaptive immune response mechanisms and tissue damage by CD4+ T helper and CD8+ $\mathrm{T}$ cytotoxic cells. The role of NK cells in AIH is not fully clarified, although NK cells might be attacking directly the liver parenchyma or contributing to damage through cytokine secretion and/or cell to cell contact [24]. We investigated the possible association between genetic variants of killer cell immunoglobulin-like receptors (KIR2DS1 and 2DS4) and the susceptibility to AIH-I in children. Previous studies have investigated these polymorphisms with several diseases, especially autoimmune diseases, but few researches have been carried out to determine these associations with pediatric onset AIH-I. KIR activating genes (KIR2DS1 and KIR2DS4) are the extensively studied KIR genes as they have been shown to be crucial in human immune response mechanisms. High frequencies of these genes have been described in various autoimmune disorders $[15,16]$.

In our study, we noticed that the KIR2DS1 and KIR2DS4 genes were significantly associated in with AIH-I patients than controls with 13.22- and 7.4-fold of increased risk to develop the disease. The frequencies of KIR2DS4-full length allele (KIR2DS4-FL) and KIR2DS4 22 bp deletion allele (KIR1D) were significantly higher in AIH-I patients and controls, respectively. Furthermore, the homozygous variant (KIR2DS4-full/full) predominate significantly in patients compared to the homozygous variant (KIR2DS4-del/del) among controls. The KIR Bx haplotype had a significant higher frequency in AIH-I patients with a 13.22-fold increased risk to develop AIHI, while the KIR AA haplotype showed higher frequency among controls.

These findings were in agreement with Littera et al. [15], who found that the frequency of the activating KIR2DS1 gene in patients compared to controls was $57 \%$ vs. $43.9 \%[P=0.028$, OR 1.69 (95\% CI $1.05-2.75)]$, but they recognized similar distribution of KIR AA and KIR Bx haplotypes between the AIH and control groups. These results support the hypothesis of the direct contribution of KIR2DS1-positive NK cells in AIH-I pathogenesis through shifting NK-cell receptor signaling towards the activating arm. Thus, the observed predictive potential of activating KIR gene KIR2DS1 makes it a suitable genetic biomarker for early onset AIH-I.

Our results were also in line with Podhorzer et al. [16], who reported higher frequency of the full length allele of KIR2DS4 (KIR2DS4-FL) in pediatric AIH (PAH). The KIR2DS4-FL allele was detected in $42 \%$ of the Argentinean Caucasian population carrying the KIR2DS4 gene. They reported the presence of KIR2DS4-FL in 70\% of PAH patients with the homozygous KIR2DS4-FL that was significantly detected in $\mathrm{PAH}$ patients than controls (33\% vs. $18 \%)$, while they found that homozygous KIR1D (KIR2DS4-del/del) was associated with a protective effect $(P$ 0.0001, OR $=0.3,95 \%$ CI $0.2-0.5)$. Moreover, Flores et al. [25] showed that the functional alleles of KIR2DS4 predominated in pediatric AIH patients while the KIR1D was common in most healthy Caucasian populations studied which support its protective effect against autoimmune hepatitis. Several studies have found an association between KIR activation genes and autoimmune diseases susceptibility. For instance, KIR2DS1 has been reported to be associated with psoriasis, systemic lupus erythematosus, and scleroderma [26-30].

Although KIR A haplotypes appear to provide a better immune response against viral infections and tumor cells, while KIR B haplotypes seem to have a favorable role during pregnancy [31], we found the homozygous KIR AA haplotype more associated with controls, whereas the KIR Bx haplotype was associated with AIH1 patients. A possible explanation may be that the gene content of KIR A haplotypes with their highly polymorphic receptors provides a better immune surveillance against tumor cells, in comparison to the moderate polymorphism of the KIR B haplotypes. Such controversial role of homozygosity for KIR A haplotype in the immune system has been addressed previously $[32,33]$.

In the current work, we could detect an association between the absence of KIR2DS4 gene in AIH-I patients with positive ANA, patients on steroid therapy alone, and patients who showed complete remission, although, unexpectedly, a higher hepatitis activity index (HAI) was significant among patients lacking KIR2DS1 and KIR2DS4 genes and a higher degree of fibrosis in KIR2DS4 negative patients.

\section{Conclusions}

From this pilot study, we could conclude that children carrying KIR2DS1, -2DS4 genes, KIR2DS4-full length allele, and homozygous KIR2DS4-full/full variant may be more susceptible to develop AIH-I. Further big scale studies are required to confirm or disapprove our claim. Therefore, in the way to precision medicine, studying these genetic polymorphisms might help in tailoring management protocols and predicting outcomes in order to improve patients' survival and quality of life.

\section{Abbreviations}

AlH: Autoimmune hepatitis; AMA: Anti-mitochondrial antibody; ANA: Antinuclear antibody; ASMA: Anti-smooth muscle antibody; KIR: Killer cell

immunoglobulin-like receptor; LKM-1: Liver-kidney microsomal antibody type 1; NK: Natural killer cells

\section{Acknowledgements}

The authors would like to thank colleagues in the National Liver Institute -Menoufia University, for their valuable assistance as well as all children and their families for their cooperation throughout the whole work. 


\section{Authors' contributions}

All authors have contributed to the current work. O.B. contributed substantially in the work idea, study design, data acquisition, analysis, and interpretation. O.E. and S.B. performed the laboratory experiments, analysis, and interpretation. N.S. performed the pathological experiments, analysis, and interpretation. O.E. and O.B. drafted and revised the manuscript. All the authors have read and approved the manuscript.

\section{Funding}

No funding resources.

\section{Availability of data and materials}

The authors declare the availability of all data and materials for the submitted work upon request.

\section{Declarations}

\section{Ethics approval and consent to participate}

This study was approved by the local ethical committee for research involving human subjects in Faculty of Medicine-Benha University (the approval number is not available). The study was carried out according to the guidelines of the Declaration of Helsinki. Ethical permission, and written consents were obtained from parents/guardians after being fully informed about the study and its procedures.

\section{Consent for publication}

Not applicable.

\section{Competing interests}

The authors have no conflicts of interest to declare that are relevant to the content of this article.

\section{Author details}

${ }^{1}$ Pediatrics Department, Faculty of Medicine, Benha University, Benha, Egypt. ${ }^{2}$ Clinical and Chemical Pathology Department, Faculty of Medicine, Benha University, Benha 13511, Egypt. ${ }^{3}$ Pathology Department, Faculty of Medicine, Benha University, Benha, Egypt. ${ }^{4}$ Medical Biochemistry and Molecular Biology Department, Faculty of Medicine, Benha University, Benha, Egypt.

\section{Received: 16 March 2021 Accepted: 30 August 2021}

\section{Published online: 12 September 2021}

\section{References}

1. Aizawa Y, Hokari A (2017) Autoimmune hepatitis: current challenges and future prospects. Clin Exp Gastroenterol 10:9-18. https://doi.org/10.2147/ CEG.S101440

2. Pathak S, Kamat D (2018) Autoimmune hepatitis in children. Pediatr Ann 47: e81-e86. https://doi.org/10.3928/19382359-20180126-01, 2

3. Muratori P, Lenzi M, Cassani F, Lalanne C, Muratori L (2017) Diagnostic approach to autoimmune hepatitis. Expert Rev Clin Immunol 13:769-779. https://doi.org/10.1080/1744666X.2017.1327355, 8

4. Vivier E, Tomasello E, Baratin M, Walzer T, Ugolini S (2008) Functions of natural killer cells. Nat Immunol 9:503-510. https://doi.org/10.1038/ni1582, 5

5. Jiao G, Wang B (2016) NK cell subtypes as regulators of autoimmune liver disease. Gastroenterol Res Pract 2016:6903496. https://doi.org/10.1155/2016/ 6903496, 6903496

6. Jeffery HC, Braitch MK, Bagnall C, Hodson J, Jeffery LE, Wawman RE, Wong LL, Birtwistle J, Bartlett H, Lohse AW, Hirschfield GM, Dyson J, Jones D, Hubscher SG, Klenerman P. Adams DH, Oo YH (2018) Changes in natural killer cells and exhausted memory regulatory T cells with corticosteroid therapy in acute autoimmune hepatitis. Hepatol Commun 2:421-436. https://doi.org/10.1002/hep4.1163, 4

7. Mele D, Bossi G, Maggiore G, Oliviero B, Mantovani S, Bonelli B, Mondelli MU, Varchetta S (2018) Altered natural killer cell cytokine profile in type 2 autoimmune hepatitis. Clin Immunol 188:31-37. https://doi.org/10.1016/j. clim.2017.12.004

8. Xiao F, Ai G, Yan W, Wan X, Luo X, Ning Q (2018) Intrahepatic recruitment of cytotoxic NK cells contributes to autoimmune hepatitis progression. Cel Immunol 327:13-20. https://doi.org/10.1016/j.cellimm.2017.12.008

9. Norris S, Collins C, Doherty DG, Smith F, McEntee G, Traynor O, Nolan N, Hegarty J, O'Farrelly C (1998) Resident human hepatic lymphocytes are phenotypically different from circulating lymphocytes. J Hepatol 28:84-90. https://doi.org/10.1016/s0168-8278(98)80206-7, 1

10. Martinet L, Smyth MJ (2015) Balancing natural killer cell activation through paired receptors. Nat Rev Immunol 15:243-254. https://doi.org/10.1038/nri3799, 4

11. Wilson MJ, Torkar M, Haude A, Milne S, Jones T, Sheer D, Beck S, Trowsdale $\mathrm{J}$ (2000) Plasticity in the organization and sequences of human KIR/ILT gene families. Proc Natl Acad Sci U S A 97:4778-4783. https://doi.org/10.1073/pna S.080588597, 9

12. Marsh SGE, Parham P, Dupont B, Geraghty DE, Trowsdale J, Middleton D, Vilches C, Carrington M, Witt C, Guethlein LA, Shilling H, Garcia CA, Hsu KC, Wain H (2003) Killer-cell immunoglobulin-like receptor (KIR) nomenclature report, 2002. Immunogenetics 55(4):220-226. https://doi.org/10.1007/s002 51-003-0571-z

13. Uhrberg M, Valiante NM, Shum BP, Shilling HG, Lienert-Weidenbach $K$, Corliss B, Tyan D, Lanier LL, Parham P (1997) Human diversity in killer cell inhibitory receptor genes. Immunity 7:753-763. https://doi.org/10.1016/s1 074-7613(00)80394-5, 6

14. Bashirova AA, Martin MP, McVicar DW, Carrington M (2006) The killer immunoglobulin-like receptor gene cluster: tuning the genome for defense. Annu Rev Genomics Hum Genet 7:277-300. https://doi.org/10.1146/a nnurev.genom.7.080505.115726, 1

15. Littera R, Chessa L, Onali S, Figorilli F, Lai S, Secci L, la Nasa G, Caocci G, Arras M, Melis M, Cappellini S, Balestrieri C, Serra G, Conti M, Zolfino T, Casale M, Casu S, Pasetto MC, Barca L, Salustro C, Matta L, Scioscia R, Zamboni F, Faa G, Orrù S, Carcassi C (2016) Exploring the role of killer cell immunoglobulin-like receptors and their HLA class I ligands in autoimmune hepatitis. PLoS One 11:e0146086. https://doi.org/10.1371/journal.pone.014 6086,1

16. Podhorzer A, Paladino N, Cuarterolo ML, Fainboim HA, Paz S, Theiler G, Capucchio M, López SI, Machicote A, Montal S, Podesta G, Fainboim L (2016) The early onset of type 1 autoimmune hepatitis has a strong genetic influence: role of HLA and KIR genes. Genes Immun 17:187-192. https://doi. org/10.1038/gene.2016.7, 3

17. Umemura T, Joshita S, Saito H, Yoshizawa K, Norman GL, Tanaka E, Ota M (2019) KIR/HLA genotypes confer susceptibility and progression in patients with autoimmune hepatitis. JHEP Rep Innov Hepatol 1:353-360. https://doi. org/10.1016/j.jhepr.2019.09.003, 5

18. Hennes EM, Zeniya M, Czaja AJ, Parés A, Dalekos GN, Krawitt EL, Bittencourt PL, Porta G, Boberg KM, Hofer H, Bianchi FB, Shibata M, Schramm C, Eisenmann de Torres B, Galle PR, McFarlane I, Dienes HP, Lohse AW International Autoimmune Hepatitis Group (2008) Simplified criteria for the diagnosis of autoimmune hepatitis. Hepatology 48:169-176. https://doi. org/10.1002/hep.22322, 1

19. Manns MP, Czaja AJ, Gorham JD, Krawitt EL, Mieli-Vergani G, Vergani D, Vierling JM, American Association for the Study of Liver Diseases. (2010) Diagnosis and management of autoimmune hepatitis. Hepatology 51:21932213. https://doi.org/10.1002/hep.23584, 6

20. Ishak K, Baptista A, Bianchi L, Callea F, de Groote J, Gudat F, Denk H, Desmet V, Korb G, MacSween RNM, Phillips MJ, Portmann BG, Poulsen H, Scheuer PJ, Schmid M, Thaler H (1995) Histological grading and staging of chronic hepatitis. J Hepatol 22:696-699. https://doi.org/10.1016/0168-8278(95)80226-6, 6

21. Hsu KC, Chida S, Geraghty DE, Dupont B (2002) The killer cell immunoglobulin-like receptor (KIR) genomic region: gene-order, haplotypes and allelic polymorphism. Immunol Rev 190:40-52. https://doi.org/10.1034/ j.1600-065X.2002.19004.X, 1

22. Yawata M, Yawata N, Draghi M, Little AM, Partheniou F, Parham P (2006) Roles for HLA and KIR polymorphisms in natural killer cell repertoire selection and modulation of effector function. J Exp Med 203:633-645. https://doi.org/10.1084/jem.20051884, 3

23. Christen U, Hintermann E (2016) Immunopathogenic mechanisms of autoimmune hepatitis: how much do we know from animal models? Int J Mol Sci 17:2007. https://doi.org/10.3390/ijms17122007, 12

24. Oo YH, Hubscher SG, Adams DH (2010) Autoimmune hepatitis: new paradigms in the pathogenesis, diagnosis, and management. Hepatol Int 4: 475-493. https://doi.org/10.1007/s12072-010-9183-5, 2

25. Flores AC, Marcos CY, Paladino N, Capucchio M, Theiler G, Arruvito L, Pardo R, Habegger A, Williams F, Middleton D, Fainboim L (2007) KIR genes polymorphism in Argentinean Caucasoid and Amerindian populations. Tissue Antigens 69:568-576. https://doi.org/10.1111/j.1399-0039.2007.00824.x, 6

26. Holm SJ, Sakuraba K, Mallbris L, Wolk K, Ståhle M, Sánchez FO (2005) Distinct HLA-C/KIR Genotype Profile Associates with Guttate Psoriasis. J 
Invest Dermatol 125:721-730. https://doi.org/10.1111/j.0022-202X.2005.23 879.x, 4

27. Łuszczek W, Mańczak M, Cisło M, Nockowski P, Wiśniewski A, Jasek M, Kuśnierczyk P (2004) Gene for the activating natural killer cell receptor, KIR2DS1, is associated with susceptibility to psoriasis vulgaris. Hum Immunol 65:758-766. https://doi.org/10.1016/j.humimm.2004.05.008, 7

28. Williams F, Meenagh A, Sleator C, Cook D, Fernandez-Vina M, Bowcock AM, Middleton D (2005) Activating killer cell immunoglobulin-like receptor gene KIR2DS1 is associated with psoriatic arthritis. Hum Immunol 66:836-841. https://doi.org/10.1016/j.humimm.2005.04.005, ,7

29. Fogel LA, Yokoyama WM, French AR (2013) Natural killer cells in human autoimmune disorders. Arthritis Res Ther 15:216. https://doi.org/10.1186/a $r 4232,4$

30. Pellett F, Siannis F, Vukin I, Lee P, Urowitz MB, Gladman DD (2007) KIRs and autoimmune disease: studies in systemic lupus erythematosus and scleroderma. Tissue Antigens 69 Suppl 1:106-108. https://doi.org/10.1111/ j.1399-0039.2006.762_6.x

31. Parham P, Moffett A (2013) Variable NK cell receptors and their MHC class I ligands in immunity, reproduction and human evolution. Nat Rev Immunol 13:133-144. https://doi.org/10.1038/nri3370, 2

32. Caocci G, Martino B, Greco M, Abruzzese E, Trawinska MM, Lai S, Ragatzu P, Galimberti S, Baratè C, Mulas O, Labate C, Littera R, Carcassi C, Passerini CG, la Nasa G (2015) Killer immunoglobulin-like receptors can predict TKI treatment-free remission in chronic myeloid leukemia patients. Exp Hematol 43:1015-1018.e1. https://doi.org/10.1016/j.exphem.2015.08.004, 12

33. La Nasa G, Littera R, Locatelli F, et al (2007) Status of donor-recipient HLA class I ligands and not the KIR genotype is predictive for the outcome of unrelated hematopoietic stem cell transplantation in beta-thalassemia patients. Biol Blood Marrow Transplant J Am Soc Blood Marrow Transplant 13:1358-1368. https://doi.org/10.1016/j.bbmt.2007.07.011, 11

\section{Publisher's Note}

Springer Nature remains neutral with regard to jurisdictional claims in published maps and institutional affiliations.

\section{Submit your manuscript to a SpringerOpen ${ }^{\circ}$ journal and benefit from:}

- Convenient online submission

- Rigorous peer review

- Open access: articles freely available online

- High visibility within the field

- Retaining the copyright to your article

Submit your next manuscript at $\boldsymbol{\nabla}$ springeropen.com 